\title{
БІОХІМІЧНІ ОСОБЛИВОСТІ ПЛОДІВ ЛИМОННИКА КИТАЙСЬКОГО (SCHIZANDRA CHINENSIS (TURCZ.) BAILL.)
}

Вступ. Враховуючи зростання потреб у нешкідливих рослинних субстанціях, останнім часом значну увагу приділяють нетрадиційним плодовим рослинам. До них належить лимонник китайський - цінне джерело біологічно активних сполук. Його широко використовують у народній та офріцинальній медицині.

Мета дослідження - вивчити біохімічні особливості плодів лимонника китайського, інтродукованого в Лісостепу України, ліпідну фрракцію, вміст летких сполук та мінеральний комплекс плодів лимонника сорту Садовий - 1 селекції Національного ботанічного саду імені М. М. Гришка НАН України.

Методи дослідження. Як вихідну сировину використовували плоди лимонника зазначеного сорту. Леткі сполуки досліджували хроматографрічним методом, вміст жирних кислот - методом капілярної газової хроматографрії, вміст макро- та мікроелементів - рентгенофллуоресцентним методом.

Результати й обговорення. Фітохімічний склад плодів S. chinensis вирізняється поєднанням важливих біологічно активних складових, зокрема жирних та ефрірних олій з багатим мінеральним комплексом макро- і мікроелементів. У ліпідному комплексі насіння лимонника виявлено високий вміст ненасичених жирних кислот з максимальним відсотком лінолевої кислоти (69,97%). У леткій фрракції з плодів лимонника виявлено 65 компонентів, а з насіння - 75 компонентів, основними серед яких є неролідол, $\beta$-елемен, гермакрен Д. Мінеральний комплекс представлений тринадцятьма макро- і мікроелементами, основними з яких є калій, кальцій, сірка, залізо, марганець, цинк.

Висновки. Результати досліджень підтверджують високу цінність плодів лимонника китайського, інтродукованого в Лісостепу України. Хімічний їх склад вирізняється поєднанням важливих біологічно активних складових, зокрема жирних та ефрірних олій з багатим мінеральним комплексом макро- та мікроелементів, що має широкий діапазон фрармакологічної дії. Це дає підстави для широкого культивування лимонника як перспективного джерела біологічно активних сполук, які можуть бути використані для створення харчових добавок і фрітокомпозичій лікарсько-профрілактичної дії.

КЛЮЧОВІ СЛОВА: Schisandra chinensis; ліпідна фрракція; вищі жирні кислоти; леткі сполуки; макроі мікроелементи.

ВСТУП. Представники роду Лимонник (Schisandra Michx.) родини Schisandraceae Blume вічнозелені або листопадні ліаноподібні чагарники, які зростають переважно в Східній і Південно-Східній Азії та південно-східній частині Північної Америки. Найбільш відомим представником роду є лимонник китайський (Schizandra chinensis (Turcz.) Baill.) - японо-манчжурський ендемік із фррагментованим східно-азійським типом ареалу, що зростає в Китаї, Японії, Кореї, Приморському і Хабаровському краях, лісах Далекого Сходу [1-3].

Численні дослідження показали, що лимонник $є$ цінним джерелом біологічно активних сполук (вітаміни С, Е і Р, органічні кислоти, пектини, мінеральні сполуки тощо) та використовується в народній і офріцинальній медицині (c) Н. В. Скрипченко, Н. І. Джуренко, Г. В. Слюсар, 2017.
[2, 4-7]. Так, плоди лимонника китайські й тибетські лікарі застосовують 3 V ст. н. е. як тонізуючий засіб при фрізичній втомі, виснаженні нервової системи, неврастенії, гіпотонії, а насіння - для лікування сухот, бронхіальної астми, захворювань печінки і нирок, дизентерії та ін. [2, 5, 8, 9]. Вважають, що основна біологічна активність лимонника та стимулювальна дія на організм людини зумовлені наявністю лігнанів (схізандрину і його аналогів). Однак важливими його складовими, безперечно, є ліпідний комплекс, леткі (до 2 \%) та мінеральні сполуки [4, 5, 8, 9].

До важливих біологічно активних складових ліпідних комплексів, поряд із каротиноїдами і токоферолами, належать вищі жирні кислоти (ВЖК), кількісний та якісний склад і співвідношення яких зумовлюють особливий спектр біологічної дії, зокрема поліненасичені (есенціаль- 
ні) лінолева та ліноленова кислоти, що входять до групи вітаміну $F$, становлять значну частку рослинних олій, мають гормональну природу і відіграють провідну роль у синтезі простагландинів. Вони не синтезуються в організмі й повинні надходити 3зовні.

На основі концентрату, одержаного шляхом фреонової екстракції насіння лимонника, виробляють олійну біологічну добавку “Лікол", яку рекомендують для підвищення працездатності. Ліпідний комплекс насіння S. chinensis проявляє адаптогенну, тонізуючу, імуностимулювальну, протизапальну, регенеруючу дії [4, 5, 9].

Доведено, що есрірні олії, в тому числі лимонника китайського, мають потужні противірусні, протибактеріальні властивості, сприяють загоєнню пошкоджень шкіри; проявляють виражену бактерицидну дію широкого спектра, яка пригнічує активацію патогенної фрлори, значну антиоксидантну активність завдяки наявності комплексу біологічно активних сполук. Протибактеріальна активність поєднується з відсутністю токсичності та побічних впливів, а за тривалого використання ефірних олій, порівняно з антибіотиками, стійкі штами мікроорганізмів не утворюються. Відомо, що ефрірна олія лимонника має адаптогенні, антисептичні, бактерицидні, жарознижувальні, протизапальні, регенеруючі, фрунгіцидні властивості.

Останнім часом на основі плодів лимонника створено ряд препаратів: "Юрай”, “Шизандра”, “Супершилд”, “Роделим", "Рест Ейд”, “Нечурал енерджайзер”, “Биск”, “Анти-Енурез” та ін.

Протягом тривалого періоду в Національному ботанічному саду імені М. М. Гришка НАН України (НБС) проводять роботу з інтродукції, селекції та вивчення біологічно активних сполук у різних органах S. chinensis. Дослідження біологічно активних сполук у плодах тісно пов'язані із селекційним процесом та різноплановим використанням цієї цінної рослини [10-12].

Мета дослідження - вивчити біохімічні особливості плодів лимонника китайського, інтродукованого в Лісостепу України, ліпідну фрракцію, вміст летких сполук та мінеральний комплекс плодів лимонника сорту Садовий - 1 селекції Національного ботанічного саду імені М. М. Гришка НАН України.

МЕТОДИ ДОСЛІДЖЕННЯ. Для досліджень використовували повітряно-сухий рослинний матеріал (насіння, плоди) лимонника китайського сорту Садовий - 1 селекції НБС.

Якісний та кількісний склад ВЖК визначали хроматограсрічним методом на хроматографрі НР-6890 із застосуванням кварцових колонок із внутрішнім діаметром 0,35 мм, нерухома сраза була представлена 5 \% синілметилсилаксаном. Для ідентифрікації ВЖК використовували їх стандартний набір [13].

Ефрірну олію одержували методом гідродистиляції. Аналіз летких сполук здійснювали на газовому хроматограсрі Agilent Technologies 6890 із застосуванням кварцової колонки HР-5MS (30×0,25 мм). Для ідентифрікації компонентів використовували бібліотеку мас-спектрів NIST05 i WILEY07 3470000 спектрів та програми AMDIS i NIST [14].

Дослідження елементного складу плодів проводили на рентгенофрлуоресцентному аналізаторі ELVAX-MET, що дозволяє визначити кількісний вміст хімічних елементів у концентрації від 0,1 мкг/г [15].

РЕЗУЛЬТАТИ Й ОБГОВОРЕННЯ. ДОСЛідження лимонника китайського, інтродукованого в Лісостепу України, показали, що ліпідний комплекс плодів - це масляниста рідина брудно-зеленого кольору з приємним запахом та гіркуватим присмаком і складає $(34,9 \pm 1,8) \%$. Відомо, що якість рослинних олій визначається кислотним, йодним, ефрірним, перекисним числами, числом омилення тощо. Згідно з отриманими результатами, показник кислотності виділеного комплексу становить 3,9 мг гідрооксиду калію, перекисне число - 0,063, ефрірне число 136,4, число омилення - 140,3 мг гідрооксиду калію. Одним із важливих показників якості олійних екстрактів вважають йодне число, що вказує на вміст ненасичених жирних кислот і дорівнює 65,9 \%.

Ліпідний комплекс плодів лимонника вирізняється значним вмістом поліненасичених ВЖК (81,38 \%), серед яких максимальний відсоток припадає на лінолеву кислоту (69,97 \%), тоді як ліноленова кислота присутня в незначній кількості $(0,7 \%)$. Значно менший відсоток становлять мононенасичені ВЖК (15,57 \%) з домінуванням олеїнової кислоти (15,37 \%). Серед ідентифрікованих насичених ВЖК у ліпідному комплексі плодів лимонника близько 3 \% складає пальмітинова кислота, інші жирні кислоти представлені в слідовій кількості (рис. 1). Такий склад ліпідного комплексу свідчить про значну біологічну активність та можливість використання плодів лимонника китайського при створенні олійних препаратів.

Поряд із ліпідним комплексом плоди лимонника накопичують до 1,7 \% летких органічних сполук. Летка фрракція з плодів та насіння лимонника - це прозора рідина золотисто-жовтого забарвлення з інтенсивним лимонним ароматом. Характерними її компонентами є сесквітерпеноїди, моно- та біциклічні терпеноїди. Особливо 


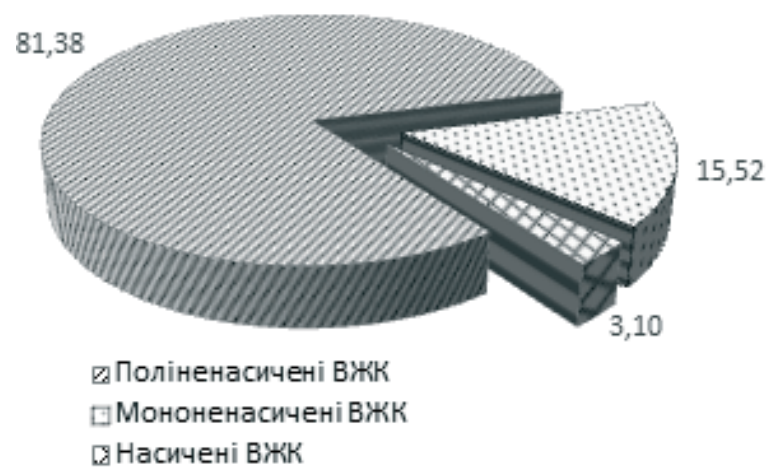

Рис. 1. Вміст вищих жирних кислот у плодах S. chinensis.

цінні такі складові леткої фрракції, як кисневмісні сполуки, спирти та ефіри, завдяки яким ефірна олія лимонника має приємний аромат.

У леткій фрракції з насіння лимонника було виявлено 75 компонентів, з яких ідентифріковано 52 (рис. 2, 3). Серед ідентифрікованих сполук домінували неролідол $(21,43 \%)$ і $\beta$-елемен $(17,61 \%)$. П'ять і більше відсотків становили цитронеллол (5,61 \%), $\beta$-селінен (6,05\%), $\alpha$-терпінеол ацетат (6,26 \%), ліналоол (6,35\%). У мен- шій кількості було виявлено 1,8-цинеол (4,13 \%), ундеканон-2 (3,40 \%), $\alpha$-кадінол (3,29 \%), терпінен-4-ол (3,17\%), $\alpha$-фрарнезен (2,82 \%), борнілацетат (2,13\%). Сім компонентів серед летких сполук не перевищували 1 \% (рис. 2, 3). Біологічно активні компоненти ефрірних олій (кислоти, спирти, альдегіди та інші) також $є$ вихідними продуктами для утворення ряду біологічно активних речовин або проміжних продуктів. Так, вуглеводні ланцюги гераніолу, ліналоолу, неролідолу, фрарнезолу $є$ ключовими проміжними продуктами на шляху біосинтезу таких біологічно активних сполук, як стероїдні гормони, феерменти, вітаміни, антиоксиданти, кислоти. Водночас значна частина (41\%) компонентів летких сполук насіння залишилась неідентифрікованою.

У леткій фрракції з плодів лимонника було виявлено 65 компонентів, 3 яких ідентифіковано лише 38 (рис. 2, 4). Домінуючими сполуками, які складали понад $10 \%$, виявились: цитронеллол $(11,13 \%)$, ундеканон-2 (10,23 \%) та цитронеллілацетат $(10,01 \%)$. Значний відсоток також становили пара-цимен (9,24\%), терпінен-4-ол (8,72 \%),

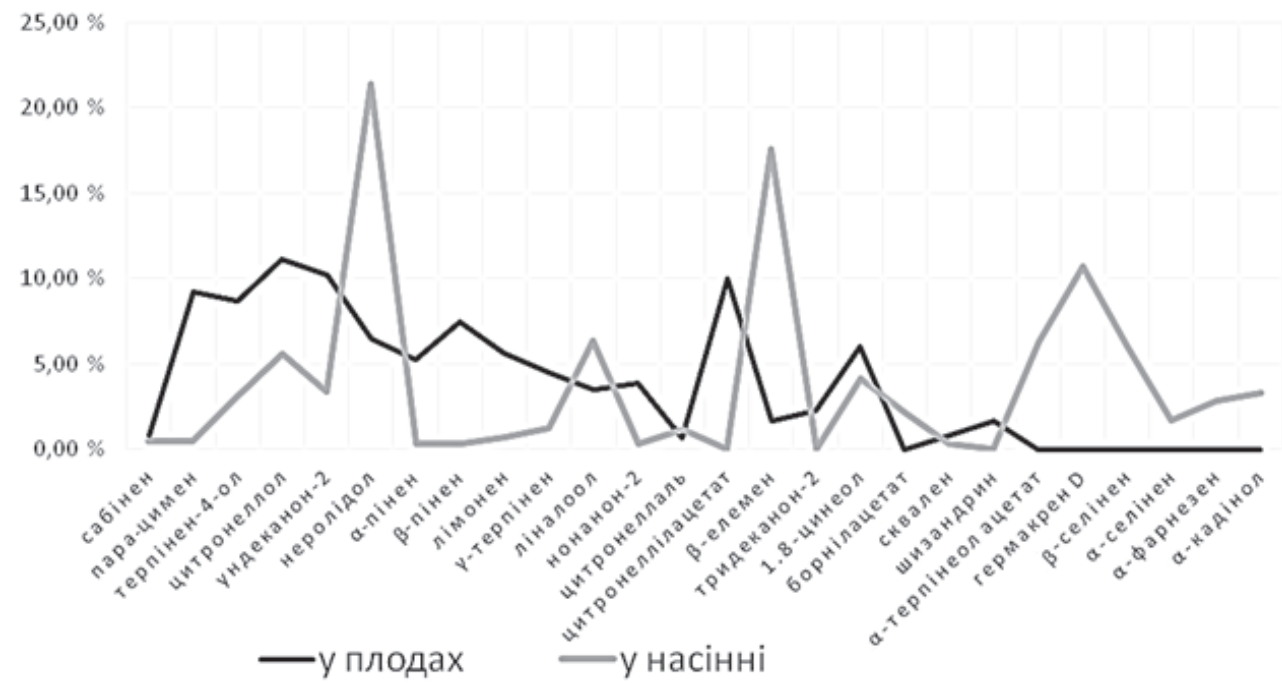

Рис. 2. Основні сполуки леткої фрракції з плодів та насіння S. chinensis.

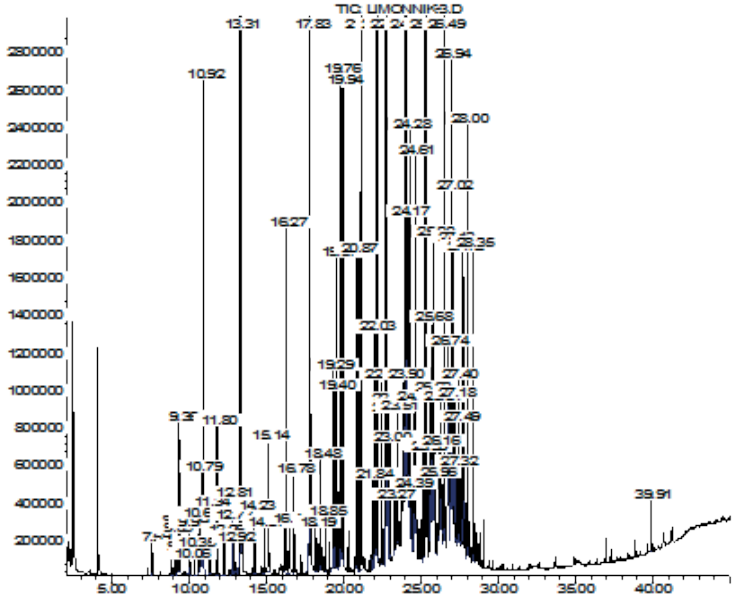

Рис. 3. Хроматограма летких сполук насіння S. chinensis.

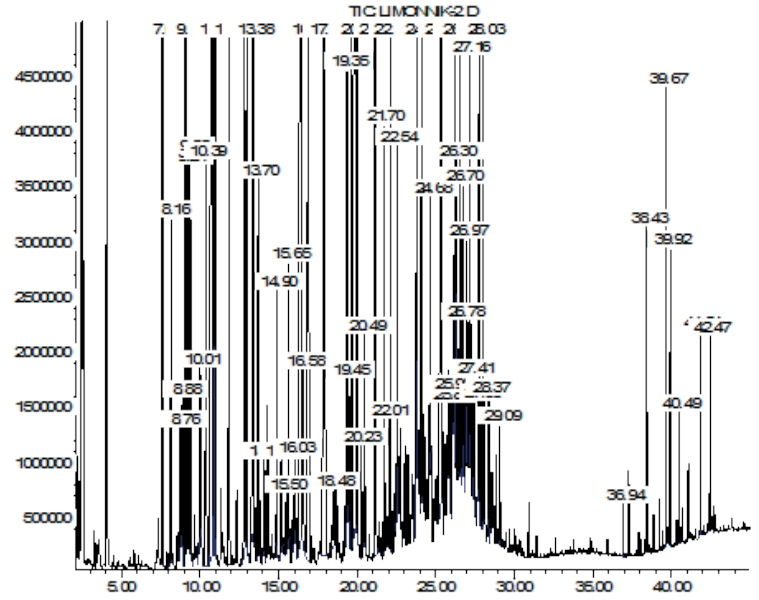

Рис. 4. Хроматограма летких сполук плодів S. chinensis. 
$\beta$-пінен (7,48 \%) та $\alpha$-пінен (5,29 \%), 1,8-цинеол $(6,02 \%)$, лімонен $(5,67 \%)$. Варто зазначити, що $\beta$-елемен було виявлено лише в ефрірній олії 3 насіння лимонника.

В есрірній олії 3 плодів та насіння лимонника виявлено незначний вміст сквалену (відповідно, 0,5 і 0,2 \%), тоді як шизандрин виявлено тільки в плодах (1,0 \%) (рис. 2, 4). Порівняння компонентного складу летких фракцій з плодів та насіння лимонника китайського показало значно вищий вміст основних компонентів у насінні.

Безперечно, значний інтерес становлять дослідження елементного складу плодів S. chinensis, який представлений складним комплексом макро- і мікроелементів. У значній кількості в плодах лимонника накопичуються калій, сірка, кальцій, залізо, марганець, цинк та інші (рис. 5, 6).

Серед макроелементів домінують калій (4495 мкг/г), який необхідний для нормальної діяльності серця, а нестача його в організмі призводить до ослаблення м'язів; сірка (3202,00 мкг/г), фрізіологічне значення і біологічну роль якої в організмі людини вивчено недостатньо, але сполуки її повинні бути в організмі в достатній кількості, адже вона входить до складу білків, срерментів, нейтралізує і виводить з організму токсини. Кальцій також інтенсивно накопичується в плодах (812,00 мкг/г), є основою скелетної системи людського організму, підтримує імунітет, незамінний для процесів згортання крові та передачі нервових імпульсів (рис. 5).

Вважають, що схильність до накопичення певних мікроелементів $€$ видоспецифрічною властивістю рослини. Плоди лимонника характеризуються здатністю до накопичення важливих для людини мікроелементів: Fe (14,9 мкг/г), Mn (14,0 мкг/г), Zn (8,4 мкг/г), які впливають на імунну систему людини, відіграють важливу роль у підтриманні оптимального рівня холестерину $(\mathrm{Fe})$, впливають на нормальний метаболізм жиру, побудову кісткової і сполучної тканин, рівень цукру в крові (Mn).

ВИСНОВКИ. 1. Дослідження ліпідного комплексу плодів лимонника китайського сорту Садовий - 1 показали, що він майже на $70 \%$ складається з поліненасичених жирних кислот, в основному лінолевої (69,97 \%), та мононенасичених (15\%) ВЖК.

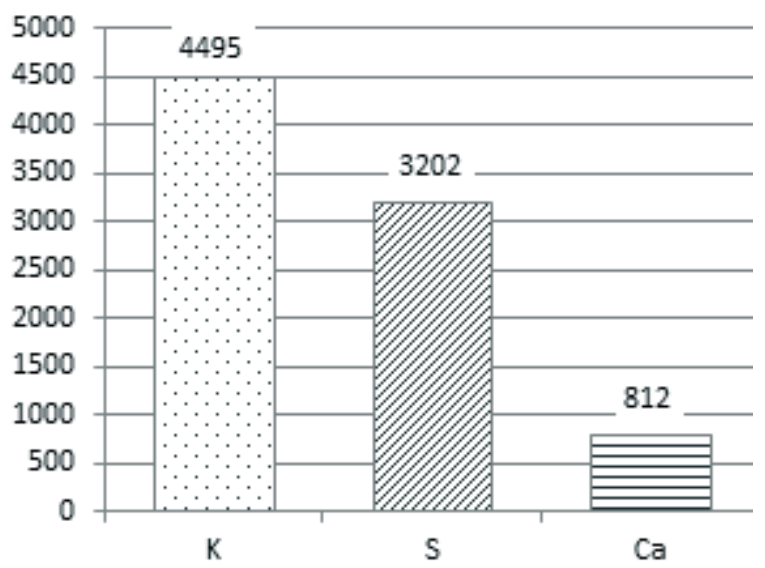

Рис. 5. Вміст (мкг/г) макроелементів у плодах S. chinensis.

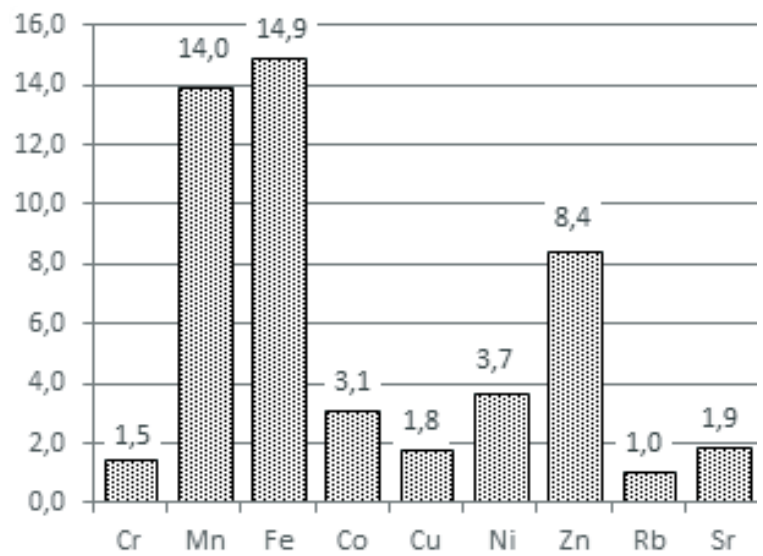

Рис. 6. Вміст (мкг/г) мікроелементів у плодах S. chinensis.

2. У леткій фрракції з насіння лимонника виявлено 75 компонентів, з яких ідентисріковано 52 (домінували неролідол-21,43\%, $\beta$-елемен 17,61 \%); з плодів - 65 компонентів, з яких ідентифіковано 38 (домінували цитронеллол 11,13 \%, ундеканон-2 - 10,23 \% та цитронеллілацетат - 10,01 \%).

3. Мінеральний комплекс плодів лимонника представлений комплексом макроелементів, основними 3 яких $є$ калій (4495 мкг/г), сірка (3202 мкг/г), кальцій (812 мкг/г), та мікроелементів: Fe (14,9 мкг/г), Mn (14,0 мкг/г), Zn (8,4 мкг/г).

4. Поєднання в плодах лимонника китайського важливих біологічно активних складових (ліпідний комплекс, леткі органічні сполуки, мінеральний комплекс макро- і мікроелементів) зумовлює широкий діапазон фрармакологічної дії та може використовуватись при створенні сучасних харчових добавок і фрітозасобів лікувально-профрілактичного спрямування. 


\section{СПИСОК ЛІТЕРАТУРИ}

1. Витковский В. Л. Плодовые растения мира : монографрия / В. Л. Витковский. - СПб. ; М. ; Краснодар : Лань, 2003. - 592 с

2. Культурная фрлора России: Актинидия. Лимонник : монография / [Колбасина Э. И., Соловьева Л. В., Тульнова Н. Н. и др.]. - М. : Россельхозакадемия, 2008. - 328 c.

3. Колбасина Э. И. Актинидии и лимонник в России (биология, интродукция, селекция) : монография / э. И. Колбасина. - М. : Россельхозакадемия, 2000. $264 \mathrm{c}$.

4. Лекарственные растения: самая полная энциклопедия : монография / А. Ф. Лебеда, Н. И. Джуренко, А. П. Исайкина, В. Г. Собко. - М. : АСТ-Пресс, 2010. $912 \mathrm{c}$.

5. Кобзар А. Я. Фармакогнозія в медицині : навч. посіб. / А. Я. Кобзар. - К. : Медицина, 2007. - 543 с.

6. Орлин Н. А. О биологически активных веществах лимонника китайского / Н. А. Орлин // Междунар. журн. прикл. и фрунд. исследований. - 2009. - № 4. C. 110-115.

7. Биологически активные вещества растительного происхождения : монография : в 3 т. / Б. Н. Головкин, Р. Н. Руденская, И. А. Трофимова, А. И. Шретер. - М. : Наука, 2001. - 764 с.

8. Фармакогнозія з основами біохімії рослин : монограсрія / за ред. В. М. Ковальова. - Х. : Прапор, 2000. - 703 c.

\section{REFERENCES}

1. Vitkovskiy, V.L. (2003). Plodovye rasteniya mira [World fruit plants]. Saint-Petersburg - Moscow Krasnodar: Lan [in Russian].

2. Kolbasina, E.I., Solovyova, L.V., Tulnova, N.N., Kozak, N.V., \& Skrypchenko, N.V., \& Moroz, P.A. (2008). Kulturnaya flora Rossii: Aktinidiya. Limonnik [Cultural Flora of Russia]. - Moscow: Rosselhozakademiya [in Russian]

3. Kolbasina, E.I. (2000). Aktinidiya i limonnik v Rossiyi (biologiya, introduktsiya, selektsiya) [Actinidia and Cninese magnolia vine in Russia (biology, introduction, selection)]. - Moscow: Rosselhozakademiya [in Russian].

4. Lebeda, A.F., Dzhurenko, N.I., Isaykina, A.P., \& Sobko, V.G. Lekarstvennyie rasteniya: samaya polnaya entsiklopediya [Medicinal plants: the most complete encyclopedia]. Moscow: AST-Press [in Russian].

5. Kobzar, A. Ya. (2007). Farmakohnoziia v medytsyni [Pharmacognosy in medicine]. Kyiv: Medytsyna [in Ukrainian].

6. Orlin, M.A. (2009). O biologicheski aktivnykh veschestvakh limonnika kitayskogo [On biologically active substances of Chinese magnolia vine]. Mezhdunar. zhurn. prikl. i fund. issledovaniy - International Journal of Applied and Fundamental Investigations, 4, 110-115 [in Russian].

7. Golovkin, B.N., Rudenskaya, R.N., Trofimova, I.A., \& Shreter, A.I. (2001). Biologicheski aktivnyie veschestva
9. Турищев С. Н. Растительные адаптогены / С. Н. Турищев // Фармация. - 2002. - 50, № 6. C. $44-45$.

10. Клименко С. В. Сорта плодовых и ягодных растений селекции Национального ботанического сада им. Н. Н. Гришко НАН Украины : монограсрия / С. В. Клименко, Н. В. Скрипченко. - К. : Изд-во Укр. фритосоциологического центра, 2013. - 104 с.

11. Шайтан И. М. Интродукция и селекция южных и новых плодовых растений : монография / И. М. Шайтан, П. А. Мороз, С. В. Клименко. - К. : Наукова думка, 1983. -216 c.

12. Дослідження компонентного складу ефірної олії Schizandra chinensis / Н. В. Скрипченко, Н.І.Джуренко, О. П. Паламарчук, П. А. Мороз // Таврійський наук. вісн. - 2014. - 88. - С. 181-186.

13. Методи визначення показників якості рослинницької продукції : посібник. - К. : Алефра, 2000. $112 \mathrm{c}$.

14. Черногород Л. Б. Эфрирные масла некоторых видов рода Achillea L., содержащие фррагранол / Л. Б. Черногород, Б. А. Виноградов // Растительные ресурсы. - 2006. - 42, вып. 2. - С. 61-68.

15. Методические указания по проведению энергодисперсионного рентгенофлуоресцентного анализа растительных материалов : справочник / под ред. ю. И. Логинова. - М. : Колос, 1983. - 43 с. rastitelnogo proishozhdeniya [Biologically active substances of vegetable origin]. (Vols. 1-3). - Moscow: Nauka [in Russian].

8. Kovalov, V.M. (Ed.). (2000). Farmakohnoziia z osnovamy biokhimii roslyn [Pharmacognosy with the bases of plant biochemistry]. Kharkiv: Prapor [in Ukrainian].

9. Turishchev, S.N. (2002). Rastitelnyie adaptogeny [Plant adaptogenes]. Farmatsiya - Pharmacy, 50, (6), 44-45 [in Russian].

10. Klimienko, S.V., \& Skrypchenko, N.V. (2013). Sorta plodovykh i yagodnykh kultur selektsii Natsionalnogo botanicheskogo sada im. N.N. Grishko [The varieties of fruit and berry plants, selected in N. Grishko National Botanical Garden]. Kiev: Izdatelstvo Ukrainskogo fitosotsiologicheskogo tsentra [in Russian].

11. Shaytan, I.M., Moroz, P.A., \& Klimienko, S.V. (1983). Introduktsiya i selektsiya yuzhnykh i novykh plodovykh rasteniy [Introduction and selection of southern and new fruit plants]. Kyiv: Naukova dumka [in Russian].

12. Skrypchenko, N.V., Dzhurenko, N.I., Palamarchuk, O.P., \& Moroz, P.A. (2014). Doslidzhennia komponentnoho skladu efirnoi olii Schizandra chinensis [The research of the component composition of essential oil of Schizandra chinensis]. Tavriiskyi nauk. visn. - Taurian Scientific Journal, 88, 181-186 [in Ukrainian]. 
13. Metody vyznachennia pokaznykiv yakosti roslynnytskoi produktsii (2000). [The methods for determining of the quality of crop production]. Kyiv: Alefa [in Ukrainian].

14. Chernogorod, L.B., \& Vinogradov, B.A. (2006). Efirnye masla nekotorykh vidov roda Achillea L., soderzhashchie fragranol [Essential oils of some species of the genus Achillea L., containing fragranol]. Rastit. Resursy - Plant Resources, 42, (2), 61-68 [in Russian]
15. Loginov, U.I. (Ed). (1983). Metodicheskie ukazaniya po provedeniyu energodispersionnogo rentgenofluorestsentnogo analiza rastitelnykh materialov [Methodological instructions for conducting of energy-dispersive $X$-ray fluorescence analysis of plant materials]. Moscow: Kolos [in Russian].

Н. В. Скрипченко, Н. И. Джуренко, Г. В. Слюсар НАЦИОНАЛЬНЫЙ БОТАНИЧЕСКИЙ САД ИМЕНИ Н. Н. ГРИШКО НАН УКРАИНЫ, КИЕВ

\section{БИОХИМИЧЕСКИЕ ОСОБЕННОСТИ ПЛОДОВ ЛИМОННИКА КИТАЙСКОГО (SCHIZANDRA CHINENSIS (TURCZ.) BAILL.)}

\section{Резюме}

Вступление. Учитывая рост потребностей в безвредных растительных субстанциях, в последнее время значительное внимание уделяют нетрадиционным плодовым растениям. К ним относят лимонник китайский - ценный источник биологически активных соединений. Его широко используют в народной и офрицинальной медицине.

Цель исследования - изучить биохимические особенности плодов лимонника китайского, интродуцированного в Лесостепи Украины, липидную фрракцию, содержание летучих соединений и минеральный комплекс плодов лимонника сорта Садовый - 1 селекции Национального ботанического сада имени Н. Н. Гришко НАН Украины.

Методы исследования. В качестве исходного сырья использовали плоды лимонника указанного сорта. Летучие соединения исследовали хроматографическим методом, содержание жирных кислот методом капиллярной газовой хроматографии, содержание макро- и микроэлементов-рентгенофрлуоресцентным методом.

Результаты и обсуждение. Фитохимический состав плодов S. chinensis отличается сочетанием важных биологически активных составляющих, в частности жирных и эфрирных масел с богатым минеральным комплексом макро- и микроэлементов. В липидном комплексе семян лимонника выявлено високое содержание ненасыщенных жирных кислот с максимальным процентом линолевой кислоты (69,97 \%). В летучей фрракции из плодов лимонника выявлено 65 компонентов, а из семян - 75 компонентов, основными из которых являются неролидол, $\beta$-элемен, гермакрен Д. Минеральный комплекс представлен тринадцатью макро- и микроэлементов, основными из которых являются калий, кальций, сера, железо, марганец, цинк.

Выводы. Результаты исследований подтверждают высокую ченность плодов лимонника китайского, интродуцированного в Лесостепи Украины. Химический их состав отличается сочетанием важных биологически активных составляющих, в частности жирных и эфрирных масел с богатым минеральным комплексом макро- и микроэлементов, который имеет широкий диапазон фрармакологического воздействия. Это дает основания для широкого культивирования лимонника как перспективного источника биологически активных соединений, которые могут быть использованы для создания пищевых добавок и фритокомпозиций лечебно-профилактического действия.

КЛЮЧЕВЫЕ СЛОВА: Schisandra chinensis; липидная фракция; высшие жирные кислоты; летучие соединения; макро- и микроэлементы. 


\section{BIOCHEMICAL FEATURES OF THE CHINESE MAGNOLIA VINE FRUITS (SCHIZANDRA CHINENSIS (TURCZ.) BAILL.)}

\section{Summary}

Introduction. Today the searching of new innocuous plant substances of the introduced non-traditional plants is increasingly important due to its possibility of versatile use in the pharmaceutical industry. These include Chinese Magnolia vine (Schizandra chinensis (Turcz.) Baill.) - the valuable source of bioactive compounds, which are widely used in folk and scientific medicine.

The aim of the study - to learn biochemical characteristics of fruits of Chinese Magnolia vine, introduced in Wood-steppe of Ukraine. The lipid fraction, the content of volatile compounds and the mineral composition of the Magnolia-vine (S. chinensis) fruits (the cultivar Sadovy -1), selected in M. Hryshko National Botanic Garden of NAS of Ukraine, were carried out.

Research Methods. As a raw material we used the Magnolia-vine fruits. Volatile compounds was implemented with chromatographic method, the content of fatty acids - with the method of capillary gas chromatography, the content of macro- and microelements - with X-ray fluorestcent method.

Results and Discussion. The chemical composition of the S. chinensis fruits is characterized by a combination of the important bioactive components, including fatty and essential oils with the rich mineral complex of the macroand microelements. The lipid complex of Magnolia-vine seeds is revealed a high content of unsaturated fatty acids with the highest percentage of linoleic acid (69.97\%). The 65 components are founded in volatile fractions of the fruits, and 75 components - in the seeds, the main of which are nerolidol, $\beta$-elemen, $D$. hermakren. The mineral complex is represented with 13 macro- and microelements, the main of which are potassium, calcium, sulfur, iron, manganese and zinc.

Conclusions. The results confirm the high value of the fruits of Magnolia-vine, introduced in conditions of the Wood-steppe of Ukraine. The chemical composition of the fruit is distinguished by a combination of important bioactive components, including fatty and essential oils, rich mineral complex macro- and microelements, which has a wide range of pharmacological action. This gives the base to widespread cultivation of Magnolia-vine as a promising source of biologically active compounds that can be used to create the food additives and phyto-compositions of medical-prophylactic action.

KEY WORDS: Schisandra chinensis; lipid fraction; higher fatty acids; volatile compounds; macro- and microelements.

Отримано 12.04.17

Адреса для листування: Н. І. Джуренко, Національний ботанічний сад імені М. М. Гришка НАН України, вул. Тимірязєвська, 1, Київ, 01014, Україна, e-mail: medbotanica@ukr.net. 